Citation: Hodúlová, T. (2021). Reinforcing place attachment through its disruption: An ethnographic example from the Solidarita housing estate in Prague. Colloquia Humanistica, 2021(10), Article 2607. https://doi.org/10.11649/ch.2607
Colloquia Humanistica 10 (2021)

Heritage and the Post-Socialist City:

Cultural and Social Perspectives

Article No. 2607

https://doi.org/10.11649/ch.2607

COLLOQUIA

HUMANISTICA

\title{
Tereza Hodúlová
}

Faculty of Humanities, Charles University

Prague

tereza.hodulova@seznam.cz

\section{Reinforcing Place Attachment Through its Disruption: An Ethnographic Example from the Solidarita Housing Estate in Prague}

\begin{abstract}
The Solidarita housing estate was built during the years 1946-1951 as one of the first post-war housing estates in Prague, former Czechoslovakia. Inspired by Scandinavian urban standards, architects designed Solidarita as an urban architectural experiment that combined innovative urban strategies, new technologies, collective approach, and cooperative financing. The sociospatial structure of Solidarita was influenced by the ideology of socialism - the production of an egalitarian society through a centrally planned economy and collective ownership. As a result, the estate was self-sufficient and conducive to neighborly meetings, and it strengthened their relations through its form. The political transformation, commercialization, and privatization in the 1990s caused a gradual change of the socio-spatial image of the neighborhood. Some elements of the housing complex started to lose their original function and the community character of Solidarita could be jeopardized. Using the theoretical concept of place attachment and the concept of social production of place, the aim of this paper is to show how residents of the Solidarita housing estate in Prague are attached to the
\end{abstract}

This is an Open Access article distributed under the terms of the Creative Commons Attribution 3.0 PL License (creativecommons.org/licenses/by/3.0/pl/), which permits redistribution, commercial and non-commercial, provided that the article is properly cited. (c) The Author(s), 2021.

Publisher: Institute of Slavic Studies, Polish Academy of Sciences

Editor-in-chief: Jolanta Sujecka

Conception and academic editing: Maciej Falski, Linda Kovářová 
place of their home and neighborhood and how this attachment is reconceptualized through the post-socialist socio-spatial changes of the place.

Keywords: neighborhood, post-socialist city, place attachment, urban transformation.

\section{Introduction}

$\bar{A}$ fter the 1990s, most of the former socialist countries, including the

Aczech Republic, experienced a change of the regime and faced the process of transition from a socialist to post-socialist - capitalist - system. Post-socialist cities embody not only physical, political, and economic transformation in urban environment, but also changes of socio-cultural aspects that may affect people's daily routines and their attachment to the place of their home (Tournois \& Rollero, 2020).

In this paper I discuss local residents' attachment to one of the first post-war housing estates in Prague, the Czech capital, called Solidarita (Solidarity), in the context of the social production of post-socialist space. Applying the methods of ethnographic research, I show how the gradual socio-spatial transformation of Solidarita (particularly the use of public space and the structure of public amenities) affects residents' attachment to this place, and how this attachment is currently being (re)contextualized by them. Further, employing the concept of the social production of space (Lefebvre, 1991), I discuss how place attachment intersected with the macro processes of political, economic, and social forces, revealing tensions between a neoliberal image of post-social city and residents' experiences of place and of its disruption.

Place attachment affects the everyday perception, understanding, and experience of place (Altman \& Low, 1992; Giuliani, 2003). Although place attachment provides stability in the sense of long-term bonds between a community and its home (Brown \& Perkins, 1992, p. 280), it is not static (Altman \& Low, 1992). The bond changes under the influence of people, activities, or processes negotiated in the place, and every socio-spatial change in the environment can affect it or even disrupt it. Also, as stated by Brown and Perkins: "Place attachments are integral to self-definitions, including individual and communal aspects of identity; disruptions threaten self-definitions" (Brown \& Perkins, 1992, p. 280).

According to my findings, Solidarita residents' attachment to their home and neighborhood is unusually strong. As I discuss further below, their affective bonds were not weakened by socio-spatial and urban 
changes, as was the case in similarly homogenized neighborhoods: on the contrary, they were reinforced. I argue that such transformation of a socio-spatial environment does not necessarily lead to a loss of its residents' attachment, but rather to its recontextualization or reinforcement. However, reinforcement depends on the active participation, interest, and involvement of residents in the process of creation of a new meaning of a place. In this paper, I also argue that ethnographic approaches to sociospatial urban research are crucial for any adequate analysis of meanings and values in contemporary complex society. Knowledge about aspects of place attachment may help to protect cultural symbols, local history, and a contemporary image of places such as neighborhoods and homes.

Firstly, I describe the theoretical background and methods used in my study. Employing the concept of the social production of place, I discuss the historical context and socio-spatial representation of Solidarita in the socialist and post-socialist periods. Secondly, in the ethnographic part I demonstrate the (re)conceptualization of residents' attachment to Solidarita. Finally, I conclude with a discussion of my ethnographic findings.

\section{Theoretical Background}

This study builds on the concepts of place attachment (Altman \& Low, 1992; Manzo \& Devine-Wright, 2020), and the social production of space (Lefebvre, 1991). Although the concept of place attachment originallyderives from environmental psychology, it has attracted considerable attention from researchers in a variety of research traditions, including geography, sociology, and anthropology. According to Altman and Low (1992) as well as Manzo (Manzo \& Devine-Wright, 2020), place attachment can be described as an affective bond that people establish with a specific area. For a better conceptualization, scholars engage the relationship between the concepts of place and space. Space is a geographical location, a real locality characterized by emptiness and potential to be filled with meaning (Hirsch, 1995, p. 9). By acquiring such meaning, space becomes a place. Thus, place is a space that has been given some meaning through personal, collective, or cultural processes (Hirsch, 1995; Low, 2016). An expanded definition of the concept of place can be found in The Sage Dictionary of Cultural Studies, according to which place is a site location in a certain space, which is meaningful and socially connected and characterized by identities or emotions associated with It (Barker, 2004, p. 144). This definition points to the material nature of space as well as its symbolic content. The significance of place can be metaphorical and discursive, as well as physically oriented 
(Low, 2009, p. 22). The way in which people ascribe these meanings to space and attach themselves to particular environments through their perception, understanding, and experience of the place, is place attachment (Altman \& Low, 1992; Giuliani, 2003).

In order to connect micro processes of attachment to the specific site of the Solidarita housing estate with macro-political, economic, and social forces, this study also uses the concept of the social production of space (Lefebvre, 1991). According to Lefebvre (1987, p. 30), space is a social and political product. In his view, space has been shaped and modified by political elements, which is why it can be read as a medium of struggle. The concept of the social production of space illuminates how a space or place comes into existence, and opens questions about the historical, political, or economic motives of its planning and current (re)development or transformation (Low, 2016, p. 34). Consideration of the social production of space adds another dimension to the understanding of the role of place attachments by exploring the sociopolitical milieu in which attachment exists. Attachment emphasizes the material aspects of the environment, but also uncovers the manifest and latent ideologies that underline this materiality. As Tournois and Rollero (2020) argue, in post-socialist countries, which globally face geographical, political, economic, and social discontinuities, the analysis of place attachment should be more prominent.

\section{Research Methods}

Although the majority of studies on place attachment use quantitative methods (Lewicka, 2011), Manzo (Manzo \& Devine-Wright, 2020) suggests that qualitative research has been particularly useful in revealing the political component of place attachment, challenging notions such as social conflict, power struggles, and social change. The ethnographic description presented in this paper is based on long-term fieldwork that I conducted in the Solidarita housing estate in Prague from April 2018 until 2020. In order to create a comprehensive image of the estate, I combined three qualitative research methods: observation, participant observation, and interviews. I spent a considerable amount of time walking around Solidarita and witnessing residents' daily lives - watching what happens, listening to what is said, asking questions through informal and formal interviews, writing field notes and taking photographs. To get closer to my informants and their communities, I also participated in many neighborhood events such as picnics, Easter and Christmas celebrations, flea markets, and so 
on.1 I also conducted archival research in order to gain an understanding of the historical context, focusing especially on journals such as Solidarita: Zpravodaj dobrého bydlení and Architektura ČSR.

The data I collected in the field consisted of field notes and fifteen semi-structured interviews with residents. During my research I used snowball sampling. My informants were nine women and six men, most of them from the middle socio-economic class. Eleven of them were born in Solidarita, two had some relatives there, and two moved to the estate a few years ago without any prior relation. Four of my informants were pensioners - children of the first generation of original residents, others were between 35-50 years old. Unfortunately, the group did not include anyone under the age of 35 . The interviews were analyzed to identify significant themes in relation to place, and observations and participatory observations revealed manifestations of place attachment. All of these were analyzed and coded into a series of themes and insights into situatedness in particular geopolitical contexts and power relations.

Although the following ethnographic example is not exhaustive, it is illustrative of the culture and social relations in the Solidarita housing estate in the context of place attachment. Following Hammersley and Atkinson (2007), I understand ethnography as a reflexive, flexible, creative method of gaining insight into contemporary culture, social relations and settings, a method which is able to produce precise descriptions and analyses from a holistic perspective. Ethnography helps to "illuminate the unknown", while it also "interrogates the obvious" (Fassin, 2013, p. 642), which is why I consider it to be the most suitable method to examine issues involved in the socio-spatial transformation of the Solidarita housing estate. Firstly, I describe the social production of Solidarita in the context of socialist and post-socialist city. From there, I proceed to ethnographic examples of residents' attachment to the estate.

\section{Historical Background and Present-Day Socio-Spatial Setting of Solidarita}

Like all Europe, Czechoslovakia suffered great damage in World War II. Almost 250,000 housing units were destroyed or made uninhabitable during the occupation, including 41,000 in Prague (Zarecor, 2011). Many cities were devastated and thus rebuilding and construction of houses were

I made observations during the weekdays and also during the weekends. I made 3 participatory observations of cultural events (Easter and Christmas celebration, burning witches), 6 neighbourood events (picnics, walks, music event, flea market). 
an urgent concern. The architects had an opportunity to address the housing crisis. After the war, the socio-spatial structure of Prague was influenced by the ideology of socialism, which envisaged the production of an egalitarian society through a centrally planned economy and collective ownership. The goal of socialist urban policy-makers was to reduce social inequalities (Ruoppila, 2004), therefore socialist Prague was planned to facilitate access to quality housing and social services for all inhabitants.

In 1946, the democratically elected left-wing coalition government supported the nationalization of industry and responded to the new economic and social reality by introducing economic planning. As part of the Two Year Plan, a co-operative building society called Solidarita was established, which was responsible for the implementation of a housing development project in the district of Strašnice in Prague (Špičáková \& Janečková, 2014). The architects of the Solidarita housing estate, František Jech, Karel Storch, and Hanus Majer, were inspired by housing standards based on Scandinavian models, and they advocated a housing reform. As a product of these transitional years, the project carried with it a hopeful optimism about the future and the potential for a more collective approach to neighborhood life, which was reflected in the spirit of the design and in its name - Solidarita (Solidarity) (Zarecor, 2011, p. 5).

The Solidarita housing estate was built during the years 1946-1951 on a rectangular plot measuring $880 \times 435$ meters as one of the first postwar housing estates in Prague (Zarecor, 2011). Following Scandinavian urban standards based on principles of sustainability, collectivity, and standardization, Jech, Storch, and Majer built Solidarita as a fusion of functionalism based on standardization and prefabrication, and a gardencity approach that respects the human scale in architecture in harmony with nature (Zarecor, 2011, p. 344). It took the form of mixed housing with row family houses, supplemented by four-story apartment blocks, with a total of 1,256 dwellings. Three groups of residents were among the original inhabitants - employees of the co-operative building society Solidarita and other cooperatives, families with at least four children, and people who were able to pay a certain commission to get a housing unit. Since Solidarita was a compromise between villa quarters inhabited by people with high socioeconomic status on the one hand, and industrial areas with a high share of lower status inhabitants on the other, original residents of Solidarita could be characterized as the middle socio-economic class. 


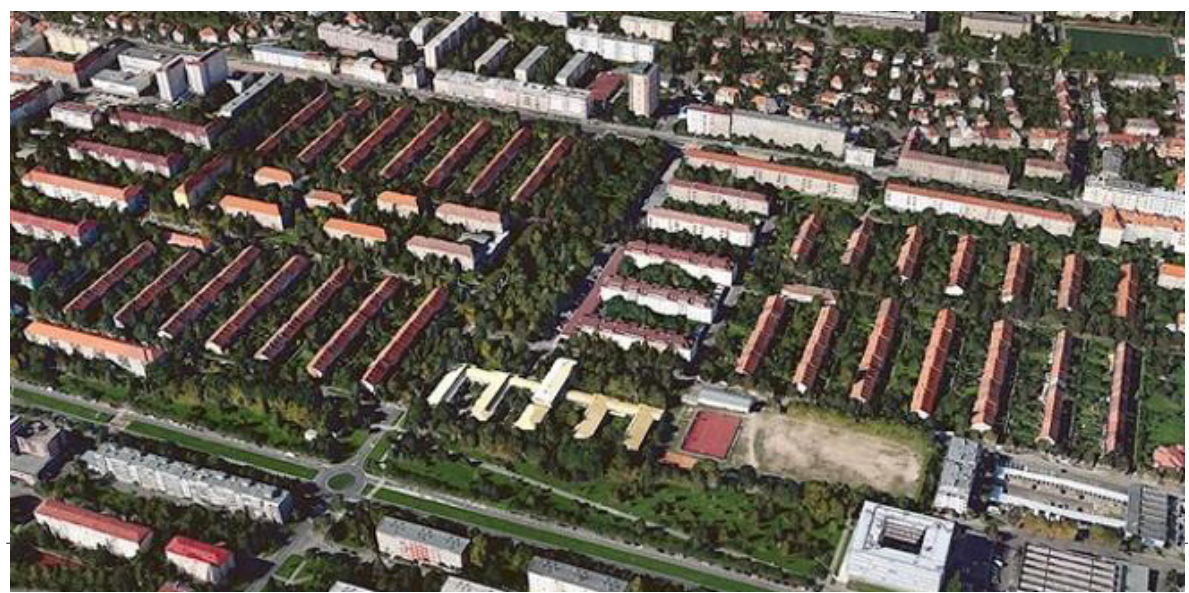

Fig. 1. Bird's eye view of the Solidarita housing estate. Source: informant's files.

In the center of the estate, a huge park was established, with the aim of supporting recreational, social, and community activities. Following state-controlled decentralization developed under socialism, these functions were also promoted by extensive public facilities located in Turnovského Street, along the central park. ${ }^{2}$

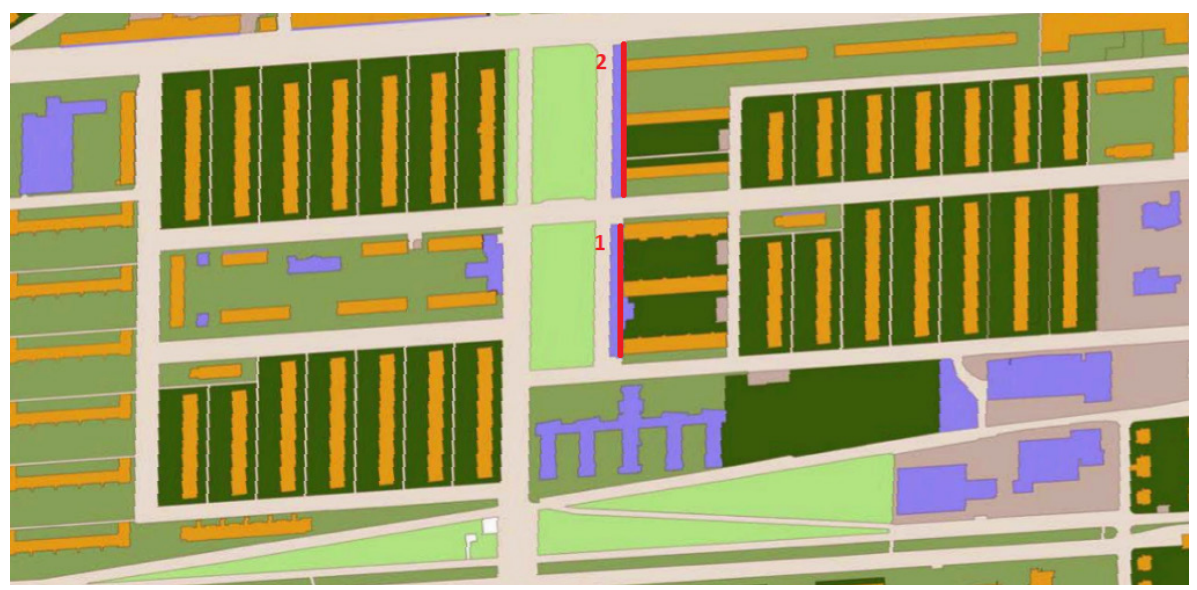

Fig. 2. Spatial distribution of Solidarita. (Holubová et al., 2012).

The estate had all the basic shops, such as a butcher, a bakery and a grocery, as well as a stationery, a haberdashery store, and a greengrocer. In addition to the shopping area in Turnovského Street, Solidarita also had

2 See Fig.2: Two parts of the central park in the middle. Public amenities (in blue); Turnovského Street along the park (in red). 
a medical facility, a nursery, a kindergarten and a general school, a cultural center with a restaurant, a theatre, a laundry, and a post office, all within walking distance. Inspired by Scandinavian models, the architects designed a large amount of greenery. Every house had a front garden, while the back of the house was lined with open, wide strips full of greenery without fences. Solidarita was not just about building row houses with gardens and picturesque pedestrian paths. It was intended to create opportunities for new relationships, community building, and outdoor living with a feeling of openness and freedom thanks to features such as minimal car traffic and the absence of fences between the rows of family homes and gardens, and generous shared green spaces.

Extensive public facilities, services, and well-planned public spaces were the intention of the urban plan (Architektura $\check{C} S R, 1947$, p. 344). As a result, the housing estate was self-sufficient and conducive to neighborly meetings, and it strengthened relations between residents through its form.

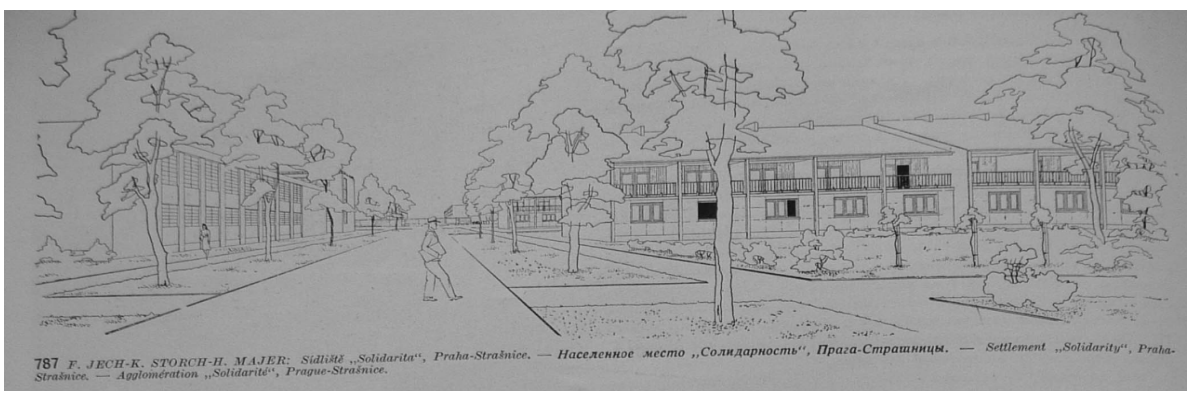

Fig. 3. Outline of Solidarita (Architektura ČSR, 1947, issue 10).

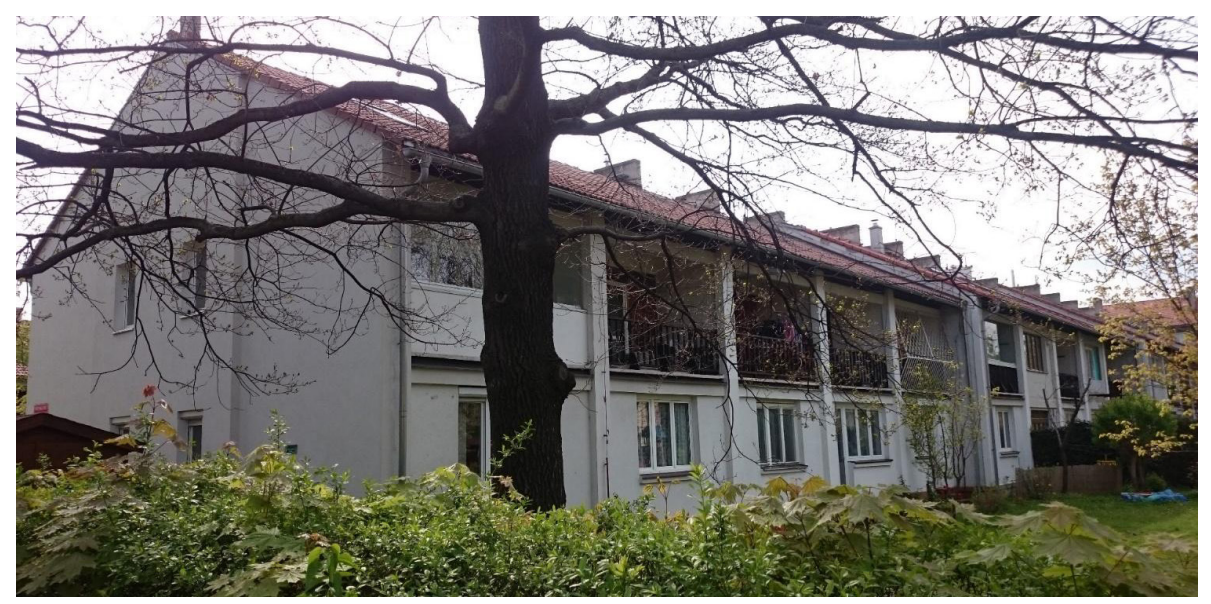

Fig. 4. Row house in the Solidarita housing estate Brigádníků Street. Photo by the author, summer 2019. 
The most important (and still ongoing) changes of the geographical space of the Czech Republic, and especially Prague, are connected with the transformation of the state after 1989 and the transition from a planned economy towards a market economy (Ouředníček, 2003). During the 1990s, Prague began to transform into a neoliberal post-socialist city driven by global financial capital. ${ }^{3}$ Contrary to the socialist period, the post-socialist city of Prague, as a prime economic center with specific conditions, faces the gradual rise of social and spatial inequalities (Špačková et al., 2016).

A gradual modernization of service facilities and households initiated after privatization in 1989 caused some elements of the Solidarita complex to lose their original function. Privatization brought changes in the status of houses in terms of their ownership. The rows of houses, together with the gardens behind, were split into separate parcels and each house became private property of its residents. Due to the character of row houses, most of the rows came under the association of the owners (forming a condominium). As a result of private ownership, large public gardens behind the row houses were fenced by each owner, so the wide-open garden was split into small, fenced parcels.

The gradual process of privatization began to change the community character of Solidarita. Even the types of service facilities and retail stores changed. From the early 1990s, supermarkets and large shopping centers gradually developed in Prague. While these places provided greater consumer convenience and choice, they also posed a threat to small local businesses and eventually caused their disappearance in many areas. Due to this competitive advantage of big supermarkets, most of the original shops perished. Today, the first part of the retail street, Turnovského, has Vietnamese shops, wine bars, a cheese shop, and a bakery. In the second part of the street ${ }^{4}$ there is a nonstop bar and a newly opened casino.

\footnotetext{
Since the end of the communist regime, political, economic, and institutional conditions have changed significantly. The national policies that accompanied the transition from a centrally planned economy towards a market economy had direct impact on urban structures of municipalities. Predominantly, state control over land and housing were abolish on both the demand and supply sides; land and housing stock were privatized and restituted power and decision making were decentralised at municipal levels; prices were liberalized and the role of planning changed. Soon, private actors became an important driving force of urban development and suddenly cities were opened to new global and international forces (Špačková, et al., 2016, p. 827).
}

4 See Fig. 2. 


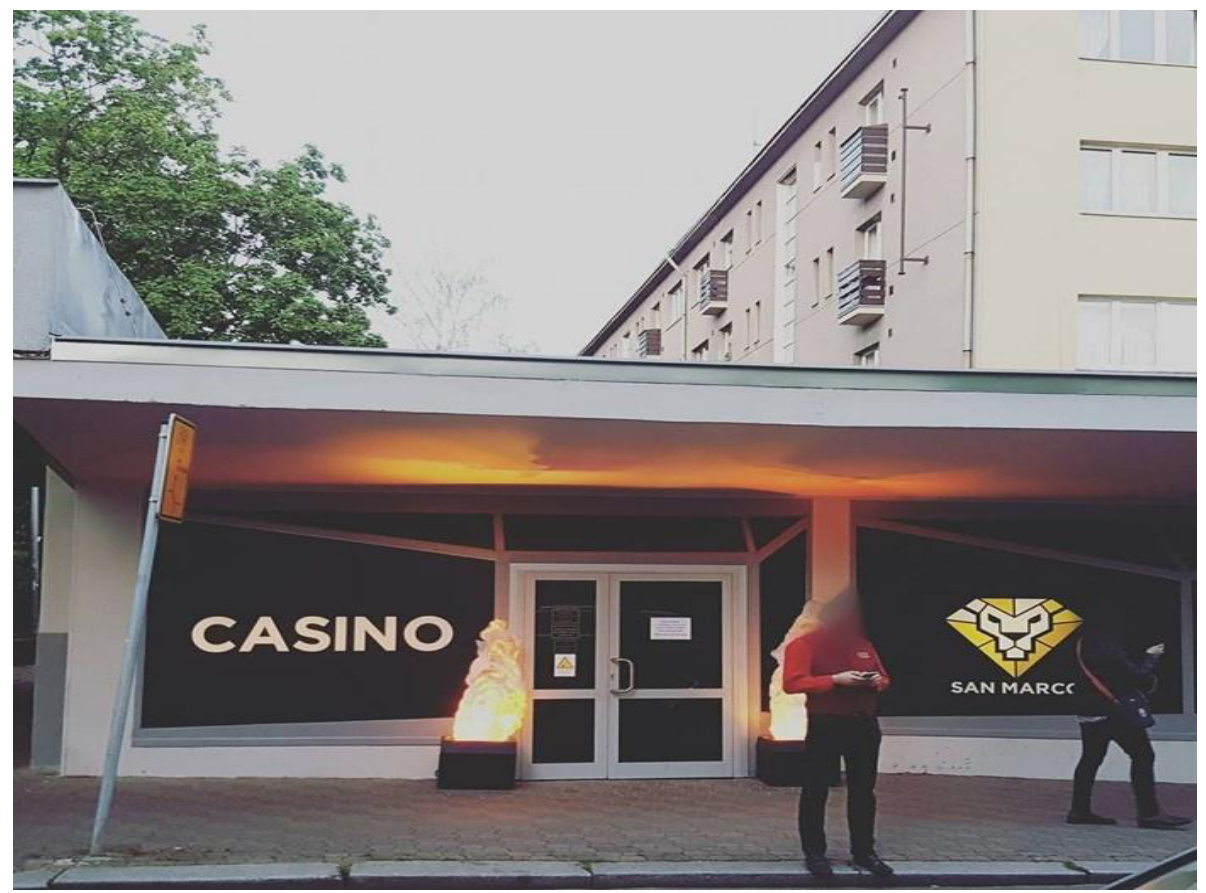

Fig. 5. Casino in Solidarita. Photo by the author, summer 2019.

\section{Place Attachment in the Solidarita Housing Estate}

Solidarita used to be, and is still considered to be, a relatively homogenous neighborhood. This homogeneity is present in the spatial structure of row houses with gardens, in the socio-economic profile of the majority of its residents, and in the specific urban image which the neighborhood has compared to its surroundings. Due to this homogeneity, Solidarita has the character of a village, even if the neighborhood is close and well connected to the city center. As I realized, to its residents, Solidarita is an area known for its strong community (Špičáková \& Janečková, 2014). This community is created by various relations - kinship, friendship, neighborly matters negotiated both historically and currently.

As some of my informants emphasized, the space of Solidarita and its specific urban characteristics and design support their recreational, social, and community activities. According to them, row houses, gardens, and Turnovského park help them to create their community. Furthermore, it is a fact that they like spending their free time somewhere in the neighborhood. 
In some interviews, the informants mentioned almost intimate knowledge of their home place. What I found interesting is that when talking about their home they mentioned the whole neighborhood, not just their own houses. Especially older informants, who were born in Solidarita, described the space of the area in every detail. Their stories about their lives in the estate included details about the location and indicated a rich and deep connection to it. The informants talked about such material realities as houses, shops, or other facilities, but also about the trees and flowers in the gardens of their neighborhood which served as its landmarks. According to them, the shopping area in Turnovského Street, together with the central park, had always served as a meeting point for neighbors. It was an ideal place to spend a sunny Sunday, have a picnic, sit in the coffee shop or on a bench, talk with their neighbors and watch children run in the park. For some of my informants, the central park was also associated with relaxation, fun, pleasure, and exploring. The interviews expressed the embodiment of meanings which they ascribed to Solidarita, and through which they attached themselves to it. These meanings were embodied in their everyday routines, walks, navigating in and knowledge about the space.

Place attachment was also imprinted in memory and remembering. The informants recalled in every detail who had lived where, who had worked in which shop, giving names and descriptions of neighbors and friends. Talking about the history of Solidarita and its narratives amounted to the process of creating a memory of the neighborhood. The knowledge of such stories and the fact of being able to tell them strengthened their attachment to the place. Surprisingly, those who were not born in Solidarita, but living there, also experienced intensive attachment and strong identification with the community even though they could not possibly identify with such stories and shared memories in terms of personal experience. As Lewicka (2008) mentions, newcomers or residents who were not born in a particular place are at the most interested in its identity and its relations. It was obvious from the interviews and from my observations that place is something that matters for the residents, regardless of whether they are locals or newcomers.

To make a connection between place attachment and the context of social production of space in post-socialist city, two following stories will show how the gradual socio-spatial transformation of Solidarita (particularly the use of public space and the structure of public amenities) affects residents' attachment to this place and how this attachment is currently being (re) contextualized by them. 


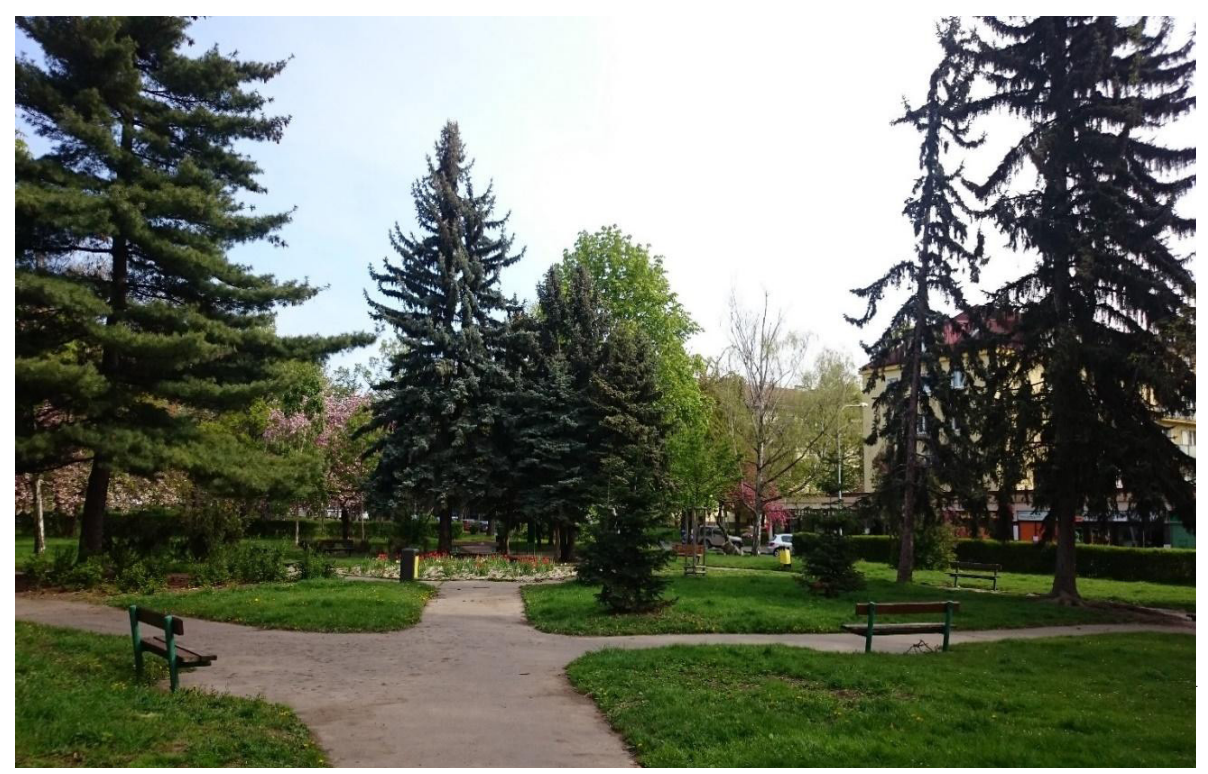

Fig. 6. Central park in the Solidarita housing estate. Photo by the author, summer 2019.

In the last few years, the part of the park which faces the casino came to be identified as "a strange place where people stopped going to and spending time". This disparate use of space could be observed throughout the day. During my observations, in summer 2019, in one part of the street and the adjacent park people were walking, sitting on the benches, reading newspaper, playing with children, and thus creating a living space together, while the other part of the street and the park was almost always empty. I was wondering if that had always been the case. According to some of my informants, a few years ago, after the casino was opened, residents stopped going to the part of the park where there were "strangers". Most residents became concerned that their neighborhood was changing. Some of my informants attributed a change in the climate of the neighborhood to the socio-spatial change (changes in the structure of public amenities and building fences) caused by the transformation in 1989. Some of them expressed what could be referred to as fear of others. "There used to be a bakery. Our families and neighbors worked there. The casino is a terrible contrast to the essence of Solidarita", as Maria, one of the oldest residents of the estate said. Especially at night, women do not feel comfortable to walk across the park, according to their parents, children are afraid to go out and play in the other part of the park: they know "it is dangerous". What was often mentioned was "others", "different groups of people", "strangers", "noise", "crime", and "trouble". 
Since the 1990s, economic development has increasingly relied on a system of social production of space based on the interest of capital. As mentioned above, after privatization most of the original shops in Turnovského Street perished due to the competitive advantage of a big supermarket near Solidarita. The casino, in turn, can be seen as an illustrative example of conflicts caused by post-socialist market-oriented municipal policy. It could be seen as a trigger of insecure affective atmosphere, and it represents new meanings of fear, insecurity, or worry. Because of the casino residents started to develop a new feeling - that "something is wrong". Some of them tried to contact officials to find out why the casino was in their neighborhood. The answer they received was that it was a privately owned building, the owner had met all the conditions and was issued a certificate of occupancy, and the officials had no right to prevent this business. Space has been shaped and modified by new neoliberal, market-oriented elements, and thus can be read as a medium of struggle (Lefebvre, 1991). Low (2016) and Manzo and Devine-Wright (2020 suggest that physical features, material and geographical components of urban environment, are parts of place attachment, especially when they offer affordances, that is, amenities or resources to support people and their social and psychological goals. Otherwise, conflicting components can cause disruption of place attachment.

When I came back, in summer 2020, at first glance I realized that something had changed. The residents soon consciously changed their strategy and they again started to hold their regular meetings with neighbors in the part of the park facing the casino. Their intention "to make the whole park livable again" was an example of a proactive process growing out of their attachment to the neighborhood. Some of them mentioned that they perceived the park as a natural part of their homes and they wanted to protect it. Place attachment was noticeable in their group discussion and in their shared interest. As Low (2016) mentions, place attachment accrues also through personal and collective experience. The story about the casino indicates residents' defensive strategies and the proactive process of their place attachment. 


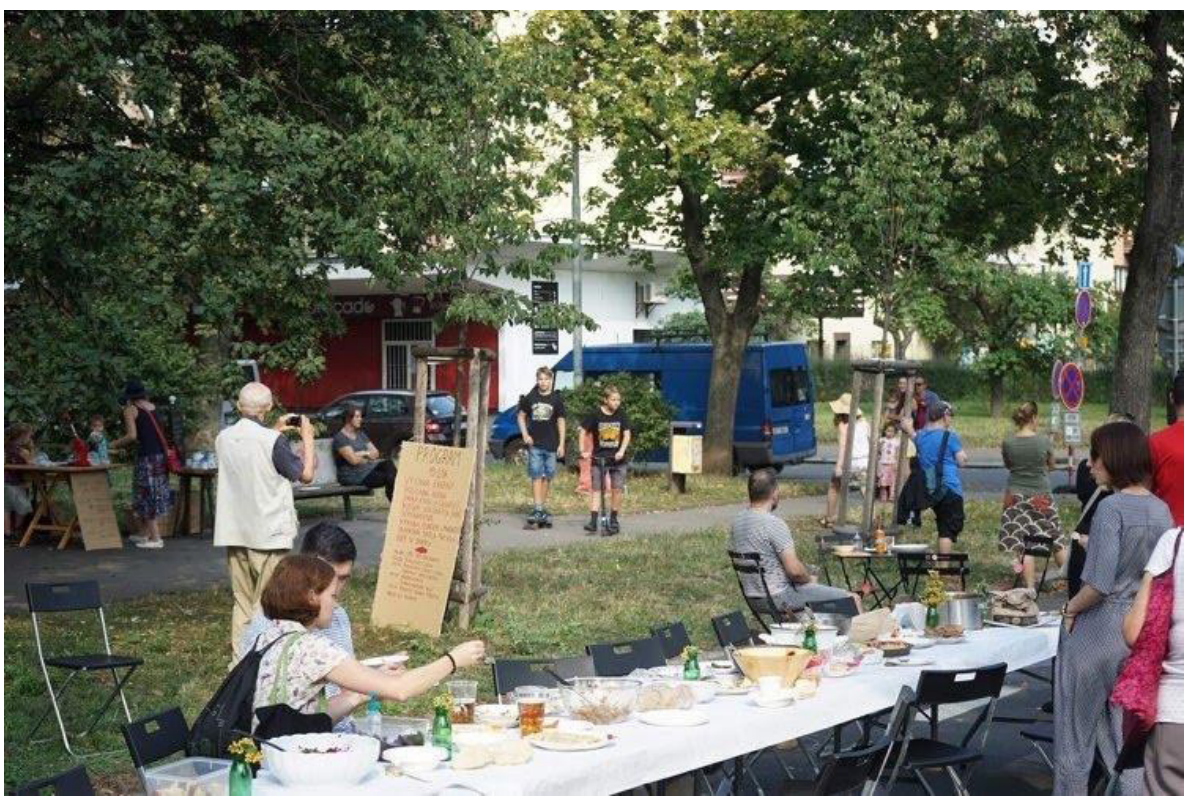

Fig. 7. Neighbors' meeting in the Solidarita housing estate. Photo by the author, summer 2020.

Another proactive process is illustrated by the informants' reaction to the inadequate shopping facilities in Turnovského Street. It is obvious that residents miss the original genius loci of the street. According to some interviewees, when Turnovského Street used to have all the basic shops it was important not just as a convenient shopping area within walking distance - it was also a place that provided an opportunity to meet your neighbor, a place where you could talk with a friend and socialize with others, a place full of meanings through which residents could attach themselves. Without this original function of the street, the community character of Solidarita could be jeopardized.

As I realized during my observations, there is a network of the neighborhood's local "suppliers" that is gradually beginning to emerge at Solidarita. This network functions on the principles of sharing economy. For example, Karel is a trained shoemaker, so he repaired shoes for Karolína in exchange for her homemade jam. They exchange vegetables, fruit, and herbs grown in their gardens. The network also works in services, as in the case of Milan, who has a lawn mower, which he regularly lends to his neighbors in the row house, who, in return, water his flower beds when he is not at home during the summer. Furthermore, residents started to hold regular neighborhood flea markets, where they exchange things they no longer use. As Karolína mentioned in our interview, due to the insufficient 
supply of services in Solidarita, residents started to help one another, just like it used to be in the past, when public amenities were adequate.

A reaction to disruption can help to mobilize citizens' participation to rebuild or reinforce a community. When residents are able to take control of the situation themselves and identify common interests and targets, they are more likely to be mobilized toward action and be empowered (Manzo \& Perkins, 2006, p. 340). Conversely, if such feelings and experiences are not well addressed, disruption could divide a community and completely change the identity of a place (Manzo \& Perkins, 2006, p. 338).

\section{Conclusion}

In this paper, using the anthropological concept of place attachment in the context of social production in a post-socialist city, I have discussed local residents' attachment to the Solidarita housing estate in Prague. I understand place attachment as the ways in which people ascribe some meanings to space and attach themselves to particular environments through their perception, understanding, and experience of the place (Altman \& Low, 1992; Giuliani, 2003).

I have shown how originally ascribed meanings are reconceptualized during the gradual transformation of the space (particularly, changes in the structure of public amenities and building fences). I have demonstrated the residents' place attachment processes based on how everyday perspective of social activity in the space of the Solidarita housing estate is negotiated through embodiment of meanings, memory and remembering, and personal and collective experience. According to my ethnographic study, the informants retain their links with the traditional past values of the neighborhood, namely, participation and community. Residents' attachment to Solidarita is more than an emotional and cognitive experience, it also includes practices that link people to place (Altman \& Low, 1992). Through the use of public space, by knowing one another and sharing, they protect the neighborhood values. As Manzo argues, attachment to the place links people and bonds them symbolically by means of values and beliefs, and practically by reinforcing the community (Manzo, 2020, p. 180). Sociospatial changes brought by a market-oriented neoliberal economy disrupted residents' routines and everyday lives, and thus affected their relationship to the place. In the case of Solidarita, the changes resulted in symbolic protest and actions, thus recontextualizing and reinforcing their attachment: place attachment was a catalyst for the mobilization of residents and their participation in response to perceived threats. Thus, I argue that such 
transformation of a socio-spatial environment does not necessarily lead to a loss of attachment, but rather to its recontextualization or reinforcement. However, reinforcement depends on the active participation, interest, and involvement of residents in the process of creation of a new meaning of a place.

\section{References}

Altman, I., \& Low, S. (Eds.). (1992). Place attachment. Springer. https://doi. org/10.1007/978-1-4684-8753-4

Barker, C. (2004). The Sage dictionary of cultural studies. Sage.

Brown, B. B., \& Perkins, D. D. (1992). Disruptions in place attachment. In I. Altman \& S. Low (Eds.), Place attachment (pp. 279-304). Springer. https://doi.org/10.1007/978-1-4684-8753-4_13

Edelstein, M. R. (2018). Contaminated communities: Coping with residential toxic exposure. Routledge.

Fassin, D. (2013). Why ethnography matters: On anthropology and its publics. Cultural Anthropology, 28(4), 621-646. https://doi.org/10.1111/cuan.12030

Giuliani, M. V. (2003). Theory of attachment and place attachment. In M. Bonnes, T. Lee, \& M. Bonaiuto (Eds.), Psychological theories for environmental issues (pp. 137-170). Ashgate.

Hammersley, M., \& Atkinson, P. (2007). Ethnography: Principles in practice. Routledge. https://doi.org/10.4324/9781315146027

Hirsch, E. (1995). Landscape: Between place and space. In E. Hirsch \& M. O 'Hanlon, The anthropology of landscape: Perspectives on place and space (pp. 1-30). Clarendon Press.

Holubová, P., Kafková, T., Kemr, L., \& Suchý, J. (2012). Sídliště Solidarita: Praha 10 Strašnice [Seminar assignment]. České vysoké učení technické, Praha.

Lefebvre, H. (1987). The everyday and everydayness (C. Levich, Trans.). Yale French Studies, 1987(73), 7-11. https://doi.org/10.2307/2930193

Lefebvre, H. (1991). The production of space (D. Nicholson-Smith, Trans.). Blackwell.

Lewicka, M. (2008). Place attachment, place identity, and place memory: Restoring the forgotten city past. Journal of Environmental Psychology, 28(3), 209-231. https://doi.org/10.1016/j.jenvp.2008.02.001

Lewicka, M. (2011). Place attachment: How far have we come in the last 40 years? Journal of Environmental Psychology, 31(3), 207-230. https://doi.org/10.1016/j.jenvp.2010.10.001

Low, S. (2009). Towards an anthropological theory of space and place. Semiotica, 2009(175). https://doi.org/10.1515/semi.2009.041

Low, S. (2016). Spatializing culture: The ethnography of space and place. Taylor \& Francis. https://doi.org/10.4324/9781315671277

Manzo, L. C. (2020). Exploring the shadow side. In L. C. Manzo \& P. Devine-Wright (Eds.), Place attachment: Advances in theory, methods and applications (2nd ed., pp. 178-190). Routledge. https://doi.org/10.4324/9780429274442 
Manzo, L. C., \& Devine-Wright, P. (Eds.). (2020). Place attachment: Advances in theory, methods and applications (2nd ed.). Routledge. https://doi.org/10.4324/9780429274442

Manzo, L. C., \& Perkins, D. D. (2006). Finding common ground: The importance of place attachment to community participation and planning. Journal of Planning Literature, 20(4), 335-350. https://doi.org/10.1177/0885412205286160

Ouředníček, M. (2003). Suburbanizace Prahy: The suburbanisation. Sociologicky časopis, 39(2), 235-253. https://doi.org/10.13060/00380288.2003.39.2.06

Ruoppila, S. (2004). Processes of residential differentiation in socialist cities: Literature review on the cases of Budapest, Prague, Tallinn and Warsaw. European Journal of Spatial Development, 2004(9).

Špačková, P., Pospíšilová, L., \& Ouředníček, M. (2016). The long-term development of socio-spatial differentiation in socialist and post-socialist Prague. Sociologický časopis / Czech Sociological Review, 52(6), 821-860. https://doi.org/10.13060/00380288.2016.52.6.288

Špičáková, B., \& Janečková, M. (2014). Sídliště Solidarita. Archiv výtvarného umění.

Tournois, L., \& Rollero, C. (2020). Should I stay or should I go? Exploring the influence of individual factors on attachment, identity and commitment in a post-socialist city. Cities, 102, Article 102740. https://doi.org/10.1016/j.cities.2020.102740

Zarecor, K. (2011). Manufacturing a socialist modernity: Housing in Czechoslovakia, 1945-1960. University of Pittsburgh Press. https://doi.org/10.2307/j.ctt7zw847

\section{Posilování vztahu k místu skrz jeho narušení: etnografický př́iklad ze sídliště Solidarita v Praze}

Sídliště Solidarita bylo postaveno v letech 1946-1951 jako jedno z prvních poválečných sídlišt’ v Praze. Architekti, inspirováni skandinávskými urbanistickými standardy, postavili sídliště jako experiment, který kombinoval inovativní urbanistické strategie, nové technologie, principy kolektivního bydlení a družstevní financovnání. Do tehdejší podoby sídliště se rovněž promítla ideologie státního socialismu, jenž byl založen na centrálně plánováném ekonomickém systému a společném vlastnictví. $\mathrm{V}$ době svého vzniku měla být Solidarita místem, které svou prostorovou formou a soběstačností podporuje a posiluje sousedské vazby a vztah rezidentů k místu svého domova. Události po roce 1989, doprovázené procesem privatizace a komercionalizace, zapříčinily postupnou transformaci socioprostorových charakteristik sousedství. Některé původní prvky sídliště ztratily svou původní funkci a spolu s postupnou individualizací začal být komunitní charakter sídliště ohrožován. Článek využívá teoretické koncepty 
přináležitost $\mathrm{k}$ místu (place attachment) a sociální produkce místa (social production of space). Jeho cílem je zjistit, jak a skrze co jsou rezidenti Solidarity připoutáni $\mathrm{k}$ místu svého domova a jak je tato přináležitost k místu re/konceptualizována v kontextu post-socialistické socio-prostorové transformace Solidarity.

Klíčová slova: post-socialistické město, přináležitost k místu, sousedství, transformace místa.

\section{Wzmacnianie więzi z miejscem poprzez jej zakłócenie: etnograficzna analiza osiedla Solidarita w Pradze}

Osiedle Solidarita zostało wzniesione w latach 1946-1951 jako jedno $\mathrm{z}$ pierwszych powojennych osiedli $\mathrm{w}$ Pradze. Architekci, inspirowani skandynawskimi standardami urbanistycznymi, zaprojektowali je jako eksperyment, który łączył innowacyjne strategie urbanistyczne, nowe technologie, zasady mieszkalnictwa zbiorowego $\mathrm{z}$ finansowaniem społecznym. W pierwotnym kształcie osiedla uwidacznia się też wpływ ideologii socjalizmu państwowego, opierającego się na centralnie planowanym systemie ekonomicznym oraz własności społecznej. W chwili swego powstania Solidarita miała być miejscem oddziałującym na mieszkańców poprzez swą formę przestrzenną oraz samowystarczalność, co miało przyczyniać się do rozwoju więzi sąsiedzkich oraz związania się mieszkańców z miejscem. Wydarzenia po 1989 roku, którym towarzyszyły procesy prywatyzacji i komercjalizacji, stały się powodem stopniowej transformacji społeczno-przestrzennych cech sąsiedztwa. Niektóre z pierwotnych elementów osiedla utraciły swoją funkcję, co wraz z postępującą indywidualizacją przyczyniło się do osłabienia wspólnotowego charakteru osiedla. W artykule oparto się na teoretycznej koncepcji przywiązania do miejsca (place attachment) oraz społecznego tworzenia miejsca (social production of space). Celem artykułu jest sprawdzenie, czy i w jaki sposób mieszkańcy Solidarity są związani z miejscem i jak owo przywiązanie do miejsca ulega re/konceptualizacji w kontekście postsocjalistycznej, społeczno-przestrzennej transformacji osiedla.

Słowa kluczowe: miasto postsocjalistyczne, przynależność do miejsca, sąsiedztwo, transformacja miasta.

Przekład z języka czeskiego Maciej Falski 


\section{Note}

Tereza Hodúlová, Faculty of Humanities, Charles University, Prague tereza.hodulova@seznam.cz

The preparation of the article was self-funded by the author.

No competing interests have been declared.

\section{Publication history}

Received: 2021-07-09, Accepted: 2021-09-03, Published: 2021-12-20 